\title{
Structure of the uterine luminal epithelium of the brush- tailed possum (Trichosurus vulpecula)
}

\author{
R. Arnold and C. D. Shorey \\ Department of Histology and Embryology, University of Sydney, New South Wales 2006, Australia
}

\begin{abstract}
Summary. Morphology and morphometry of the luminal surface of the uterus of the brush-tailed possum were studied during the oestrous cycle, in anoestrous animals and after ovariectomy.

At oestrus the secretory cells were small and the epithelium heavily ciliated. The relative surface area occupied by secretory cells reached a maximum on Day 13 when plasma progesterone concentrations are maximal. The mean apical surface area of the secretory cells also reached a maximum at this time. Both these measures decreased on Day 18 when involution of the epithelium was taking place. This process was essentially complete by Day 24 and was followed by extensive ciliogenesis.

Secretory cells from anoestrous animals appeared to have an apical surface area similar to the minimum recorded during the oestrous cycle and extensive loss of cilia did not occur. Ovariectomy caused loss of ciliated cells and a reduction in the mean apical surface area to a dimension much smaller than that measured in intact animals.
\end{abstract}

\section{Introduction}

The response of the uterine epithelium to hormonal fluctuations during the oestrous cycle has been documented for a number of eutherian species (Psychoyos \& Madden, 1971; Davies \& Hoffman, 1973, 1975; Finn \& Porter, 1975; Hammer, Samarian \& Mitchell, 1978; Geissinger, Liptrop \& Ackerly, 1979; Busch, Kuhnel \& Mootz, 1981 ; Anderson, 1982; Eroschenko, 1982). Transmission electron microscope (TEM) observations have also been reported for at least one marsupial species, namely the brush-tailed possum (Shorey \& Hughes, 1972, 1973). The aim of this study was to determine the nature of the changes in the surface morphology of the uterine epithelium and to correlate the results with TEM observations. Morphometry was also carried out in conjunction with the microscopy to determine whether ciliated cells fluctuate in number in response to a changing hormonal environment and to establish whether changes occurred in the apical surface area of secretory cells during the oestrous cycle.

The brush-tailed possum has two separate uterine horns each of which opens into one of two lateral vaginae. These then enter a single urogenital sinus (Pilton \& Sharman, 1962). The endometrium at oestrus is thin and is lined with a simple cuboidal epithelium containing ciliated and secretory cells (Shorey \& Hughes, 1973).

\section{Materials and Methods}

Details of trapping of animals, determination of oestrus and preparation of tissue for microscopy and morphometry were as given by Arnold \& Shorey (1985). Tissue for microscopy and morphometry was removed at oestrus and on Days 3,8,13,18 and 24 of the oestrous cycle with 2 or 3 animals being used for each stage. Tissue was also obtained from one anoestrous animal and 2 animals ovariectomized 4 and 14 months previously. Tissue for additional morphological observations was taken from 4 animals during anoestrus and on each of Days 1 and 2 of the cycle. 
Morphometric analysis was carried out on a Leitz semiautomatic image analyser interfaced with an HP9825B calculator and an HP2621 graphics plotter: the surface area of about 200 secretory cells and the relative areas of ciliated and secretory cells were measured from each tissue sample, using 10 photographs at $\times 1000$ magnification. Cluster analysis according to the method of Davis (1973) was carried out on the results of the morphometry.

\section{Results}

\section{Oestrus to Day 2 of the oestrous cycle}

The endometrium around the time of oestrus had a flat surface (Pl. 1, Fig. 1) and was relatively thin. The luminal epithelium was heavily ciliated and secretory cells were relatively small (Table 1). Glandular openings were narrow but were usually easy to recognize on the basis of the increased number of ciliated cells in their immediate vicinity. This increase was noted wherever glands were visible with the scanning electron microscope (SEM), regardless of the stage of the cycle.

Table 1. Results of the morphometric analysis of the uterine epithelium of brush-tailed possums during the oestrous cycle and anoestrus and after ovariectomy

\begin{tabular}{|c|c|c|c|}
\hline & $\begin{array}{l}\text { No. of } \\
\text { cells }\end{array}$ & Area $\left(\mu \mathrm{m}^{2}\right) \dagger$ & $\% \ddagger$ \\
\hline Oestrus & 351 & $25.9 \pm 10.4$ & $23.5 \pm 11.4$ \\
\hline Day 3 & 97 & $28.6 \pm 14.3$ & $40.0 \pm 5.7$ \\
\hline Day 8 & 355 & $59.7 \pm 25.0$ & $87.4 \pm 4.8$ \\
\hline Day 13 & 564 & $85.4 \pm 69.5$ & $94.5 \pm 4.1$ \\
\hline Day 18 & 280 & $33.5 \pm 13.4$ & $37.5 \pm 11.9$ \\
\hline Day 24 & 609 & $28.0 \pm 10.6$ & $33.5 \pm 8.9$ \\
\hline Anoestrus & 82 & $28.4 \pm 10.0$ & 78.5 \\
\hline \multicolumn{4}{|c|}{ Ovariectomized } \\
\hline 4 months & $397^{*}$ & $12 \cdot 9 \pm 5 \cdot 1$ & 100 \\
\hline 14 months & $331^{*}$ & $17.2 \pm 5.5$ & 100 \\
\hline
\end{tabular}

Secretory cells. The apical surfaces of the individual secretory cells were flat with the exception of a few fine hair-like ridges and scattered pleomorphic microvilli (Pl. 1, Fig. 2). Flocculent material was present in the uterine lumen (Pl. 1, Fig. 2) and in some cases was observed extruding from the openings of the uterine glands.

Ciliated cells. Ciliated cells had a flat surface and were angular in outline with the cilia interspersed with fine microvilli which occasionally branched (Pl. 1, Figs $2 \& 3$ ). This appearance continued until Day 13 of the oestrous cycle.

Stroma. The basement membrane at oestrus was thick and clearly defined. The stroma contained scattered fine collagen fibrils and was relatively acellular except in the vicinity of the epithelium where large numbers of small blood vessels, fibroblasts and undifferentiated cells were present. This appearance persisted until Day 18 of the cycle.

\section{Day 3 of the oestrous cycle}

The surface contours of the uterus on Day 3 resembled those at oestrus. There was little change in the mean surface area of the secretory cells with respect to oestrus although the percentage of epithelial surface area occupied by them had increased slightly (Table 1). 
Secretory cells. The contents of these cells appeared very similar to those observed around the time of oestrus although there was a noticeable change in the surface morphology. The outline of secretory cells at this stage was rounded and many of the apices were domed (PI. 1, Fig. 4). This correlated with increased numbers of lipid droplets in the secretory cells. Microvilli had proliferated and a single cilium had appeared on a few of the secretory cells. Flocculent material was less common although mucus and membranous vesicles adhered to some parts of the surface.

\section{Day 8 of the oestrous cycle}

This stage marked the beginning of the uterine luteal phase. The luminal surface of the endometrium was still relatively smooth although the overall thickness of the uterine wall was greater than on Day 3 of the cycle. Mean surface area of secretory cells and the percentage area of epithelium occupied by them had increased considerably when compared to values obtained on Day 3 of the cycle (Table 1).

Secretory cells. Secretory cells at this stage were angular in outline and their boundaries were clearly marked by a broad line of short close-packed microvilli although microvilli over the remainder of the cell surface were usually quite sparse. Most cell surfaces were flat although some had slight doming of the entire apex or cytoplasmic protrusions of various sizes and shapes (Pl. 2, Figs $5 \& 6$ ). These apical outgrowths were usually free of microvilli. Scattered caveolae were present on the outgrowths and also on the non-distended regions of the apical surfaces (Pl. 2, Fig. 6). Cells with a single cilium remained uncommon.

Ciliated cells. Ciliated cells on Day 8 resembled those observed at earlier stages of the oestrous cycle (PI. 2, Fig. 5).

\section{Day 13 of the oestrous cycle}

At this stage the surface of the uterus was a complex of irregular polygonal ridges and narrow branching grooves, elaborate enough to obscure glandular openings (P1. 2, Fig. 7). The mean apical surface area of secretory cells was at a maximum and the secretory cells occupied $94 \%$ of the endometrial surface (Table 1).

Secretory cells. Secretory cells on Day 13 were domed rather than flat and there was considerable variation in the apical surface area with smaller cells between the large ones (Pl. 2, Figs $7 \&$ 8). A large amount of lipid was present in the cytoplasm, either in the form of a single large droplet, usually apically situated, or a number of smaller droplets. There was also abundant rough endoplasmic reticulum, mitochondria and small membrane-bound vesicles. Cell surfaces were densely covered with short microvilli, and mucus and membranous vesicles $0.5-1.0 \mu \mathrm{m}$ in diameter adhered to the luminal surface especially to the cilia (Pl. 3, Fig. 8).

Ciliated cells. These cells occurred singly or in groups of two or three. The only indication of their presence by SEM was a tuft of cilia protruding between the apical domes of the secretory cells (Pl. 3, Fig. 8).

\section{Day 18 of the oestrous cycle}

Stromal oedema decreased on Day 18 and this was associated with a reduction in the overall thickness of the endometrium as well as a smoothing out of the luminal surface. Decreases were noted in both the mean surface area of the secretory cells and the percentage area of epithelial surface occupied by them (Table 1).

Secretory cells. Debris, consisting mainly of membranous fragments, was present in the lumen. Microvilli were extremely pleomorphic and often associated with an osmiophilic glycocalyx (Pl. 3, Fig. 9). Secretory cells were flat rather than domed and some cells appeared to be degenerating. The cytoplasm of these cells was vacuolated and the apical plasma membrane in some cases was 
discontinuous or absent. A single large lipid droplet per cell was less common than on Day 13 although about half the secretory cells present contained considerable numbers of small droplets. Some of these appeared vacuolated or crenellated. Membrane-bound structures with the morphological characteristics of secondary lysosomes were present in most secretory celis ( $\mathrm{Pl}$. 3, Fig. 9). Despite the widespread evidence of involution, actual sloughing of cytoplasmic remnants was restricted to individual cells rather than affecting extensive areas of epithelium. Cells with a single cilium appeared more prevalent than earlier in the oestrous cycle.

Ciliated cells. Some ciliated cells were being sloughed in a manner similar to that described above for secretory cells. Others, however, were undergoing ciliogenesis as evidenced by the presence of ciliary buds or cilia in a range of lengths (Pl. 3, Fig. 10).

Stroma. A network of stromal cells had accumulated under the epithelium by Day 18. About half of these had the morphological characteristics of macrophages whereas the others appeared relatively undifferentiated. The basement membrane was insignificant or discontinuous.

\section{Day 24 of the oestrous cycle}

There was a further decrease in the mean surface area of secretory cells at this stage giving a value similar to that measured at oestrus. The percentage area of epithelial surface occupied by secretory cells had also decreased but was higher than the value recorded at oestrus (Table 1).

Secretory cells. The number of lipid droplets per cell had decreased considerably by this stage and secretory cells generally resembled those of oestrus except for the relatively large number of secondary lysosomes. A few still showed apical doming but the majority were flat and the boundaries were marked by a low peripheral ridge. Some debris remained in the lumen (P1. 3, Fig. 11) although sloughing of epithelial cells had ceased. Cells with a single cilium were still present but seemed less prevalent than on Day 18 of the oestrous cycle (Pl. 3, Fig. 12).

Ciliated cells. There were considerable numbers of ciliated cells in all parts of the epithelium at this stage of the oestrous cycle (Pl. 3, Fig. 11). Some featured densely packed mature cilia (Pl. 3, Fig. 12) whereas others possessed either ciliary buds interspersed with microvilli or cilia of various lengths (Pl. 3, Fig. 12). A few cells were observed which contained one or several clusters of granules $30-50 \mu \mathrm{m}$ in diameter and in some cases single granules of similar appearance were also

\section{PLATE 1}

Fig. 1. Possum uterus at oestrus. $\mathrm{C}=$ ciliated cell, $\mathrm{G}=$ opening of gland. $\times 60$.

Fig. 2. Possum uterus at oestrus. Secretory cells (S) have a flat surface. Flocculent material (arrow) is probably shell precursor arising from uterine glands. $\mathrm{C}=$ ciliated cell. $\times 2200$.

Fig. 3. Possum uterus at oestrus showing secretory cells (S). Organelles are plentiful and there is a small amount of lipid (l) present. $\mathrm{C}=$ ciliated cell. $\times 6300$.

Fig. 4. Day 3 of the oestrous cycle. Secretory cells (S) are domed rather than flat and microvilli are more plentiful than at oestrus. A few secretory cells possess a single cilium (arrowed). $\times 2100$.

\section{PLATE 2}

Fig. 5. Day 8 of the oestrous cycle. Opening of uterine gland (arrowed) surrounded by large numbers of ciliated cells $(C) . \times 2150$.

Fig. 6. Day 8 of the oestrous cycle. Secretory cell boundaries are marked by increased numbers of microvilli (arrowed). Some apices are slightly domed. cav = caveola. $\times 6250$.

Fig. 7. Day 13 of the oestrous cycle. Folded endometrial surface characteristic of the mid-luteal phase. $\times 425$.

Fig. 8. Day 13 of the oestrous cycle. Secretory cells (S) are domed and covered in short fine microvilli. Membranous vesicles (arrowed) are probably of glandular origin. $\times 1910$. 
PLATE 1
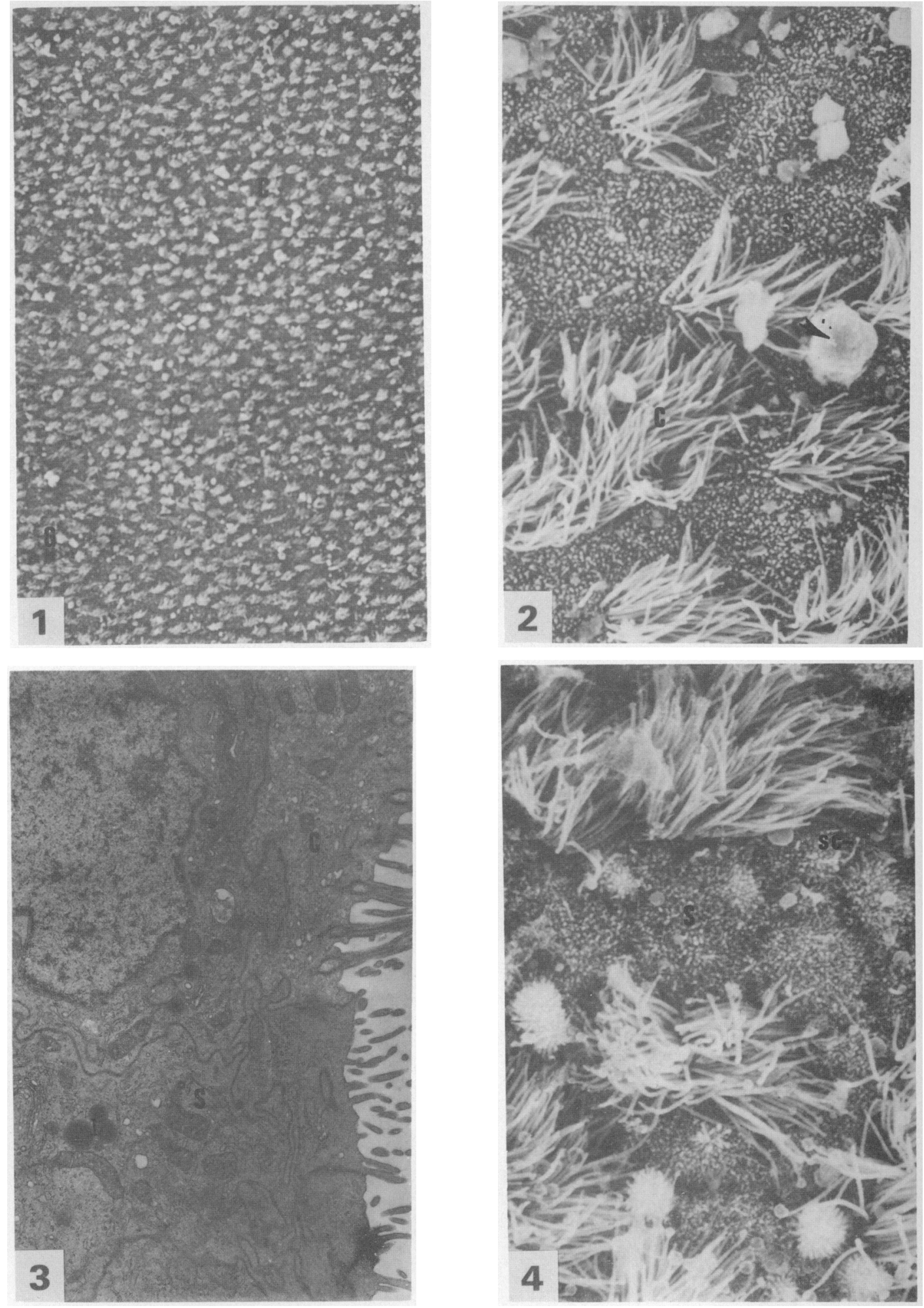

(Facing p. 568) 

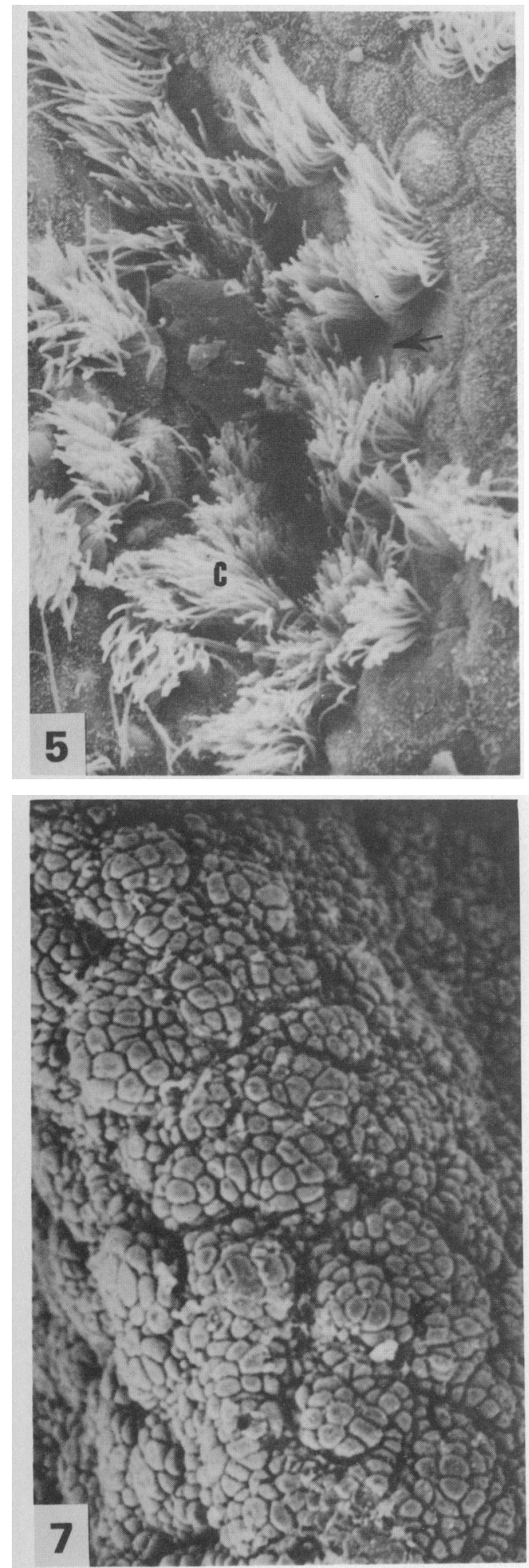
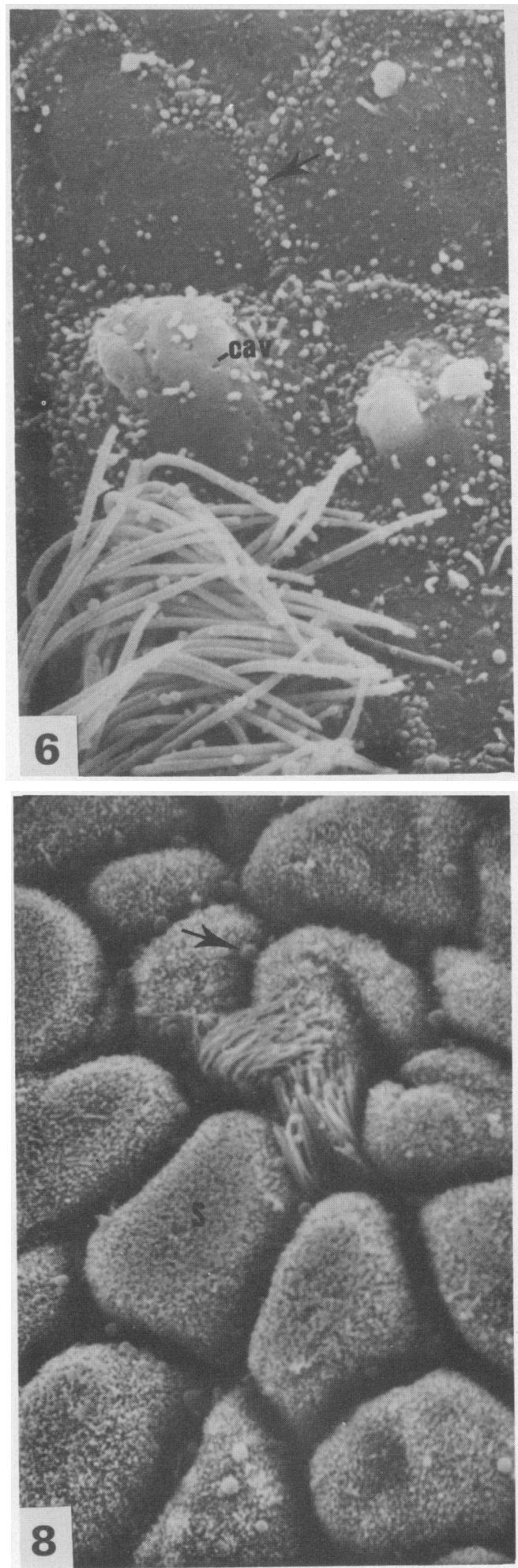

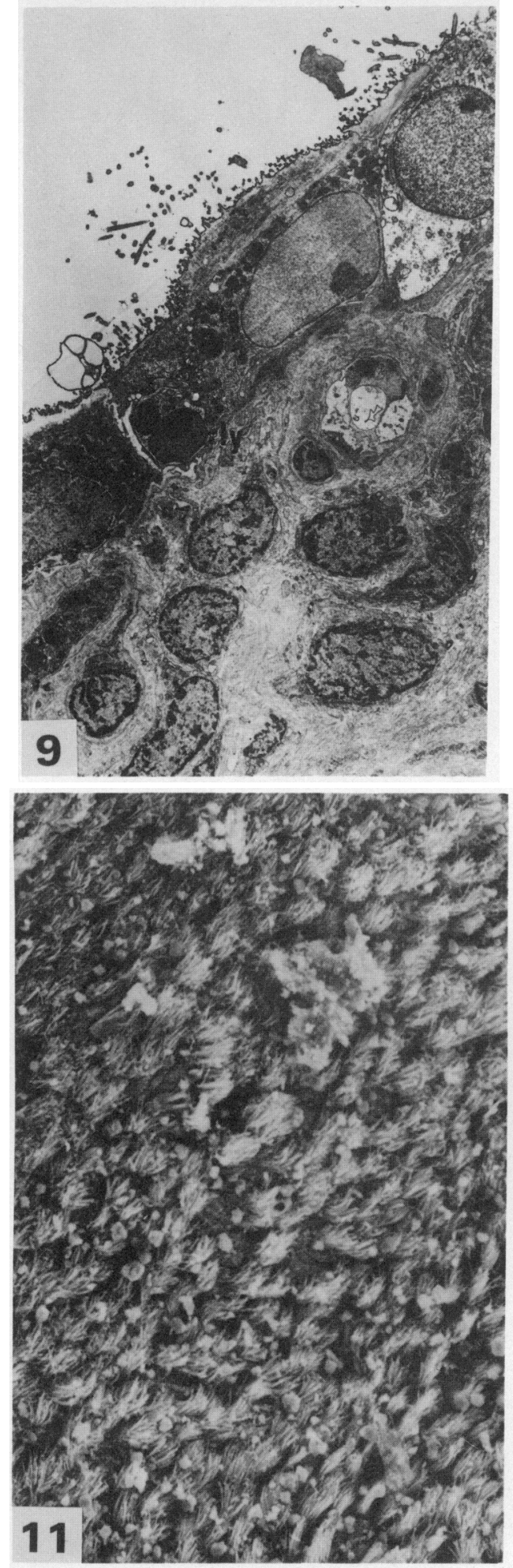
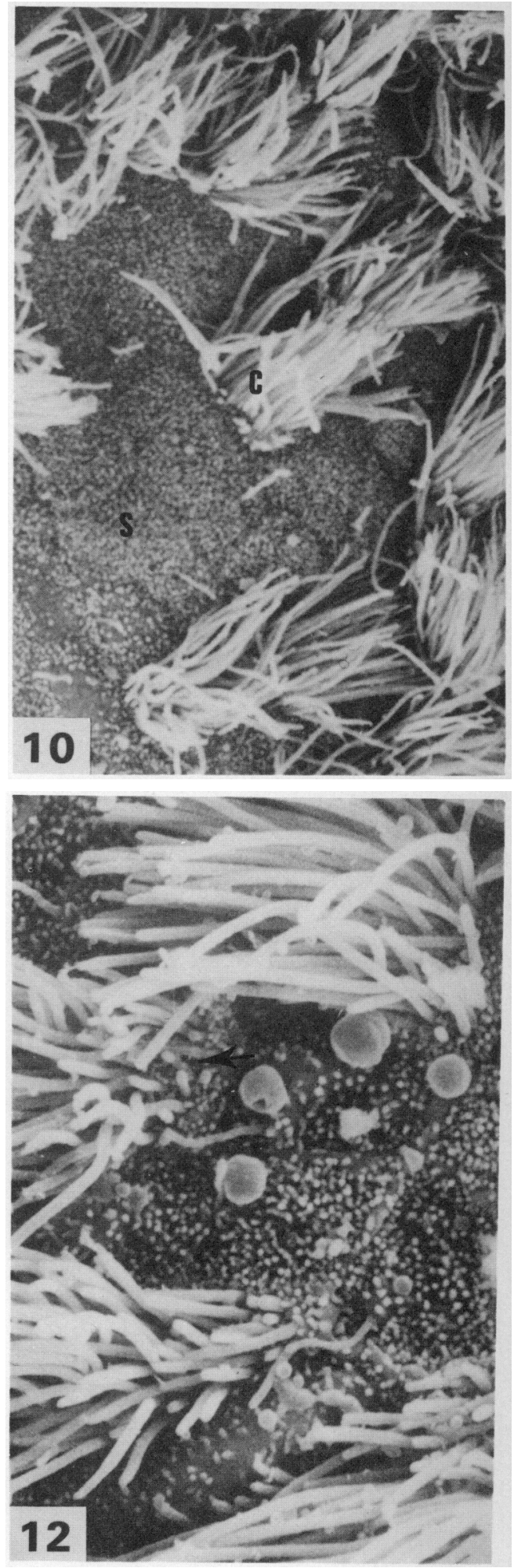
PLATE 4
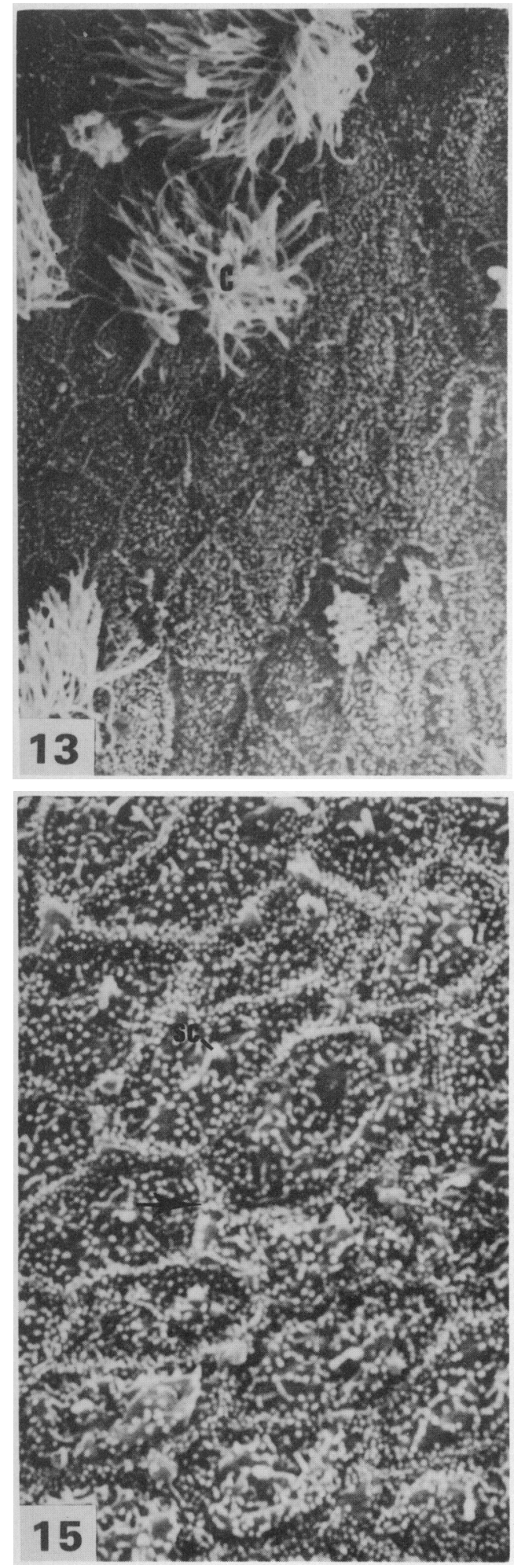
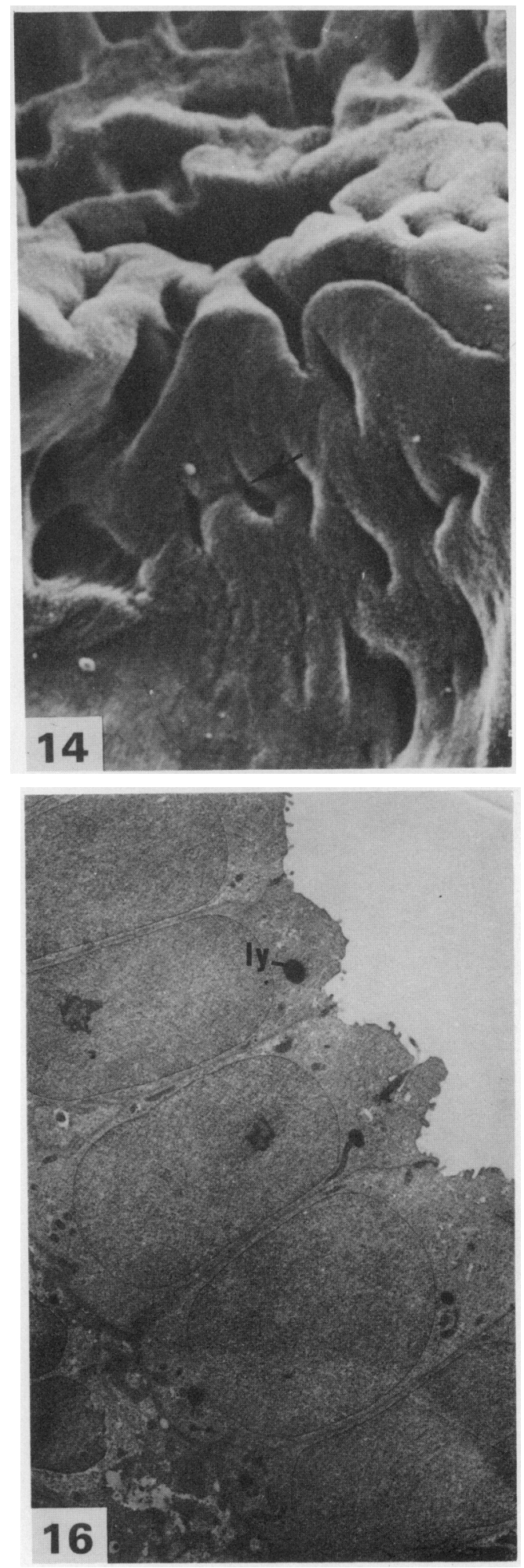
present. Other cells possessed fully formed basal bodies. Some of these were scattered throughout the apical cytoplasm and were often associated with a well-formed intracellular axoneme. Other basal bodies were adjacent to the apical plasma membrane and in some instances groups were situated beneath cytoplasmic protrusions containing several cilia.

Stroma. The basement membrane had reformed by Day 24 of the cycle and the number of cells adjacent to the epithelium and elsewhere in the stroma had decreased.

\section{Anoestrus}

The uteri from anoestrous animals were shorter and narrower than at any stage during the oestrous cycle. The endometrial surface was flat and secretory cells occupied about $78 \%$ of the epithelium. The mean apical surface area of secretory cells was similar to minimal values obtained from cycling animals (Table 1).

Secretory cells. All secretory cells observed in anoestrous uteri were flat and, although some boundaries were inconspicuous, others were demarcated by a small ridge of cytoplasm. Microvilli were short and usually sparse in distribution and many secretory cells possessed a single cilium ( $\mathrm{Pl}$. 4, Fig 13). TEM showed that secretory cells were cuboidal in profile with a high nucleus-cytoplasm ratio; organelles were sparse except for a well formed Golgi.

Ciliated cells. These resembled the ciliated cells seen in cyclic animals although ciliogenesis was never observed.

\section{After ovariectomy}

The uteri were considerably reduced in length and thickness 4 months after ovariectomy and further involution had occurred 14 months after ovariectomy. The endometrium was thin and irregularly folded and the surface penetrated at intervals by enlarged openings of uterine glands ( $\mathrm{Pl}$. 4, Fig. 14). The mean surface area of the secretory cells was smaller than that measured in anoestrous or cyclic animals (Table 1). After ovariectomy, secretory cells were usually flat or slightly corrugated and boundaries were sometimes marked by a peripheral ridge. Microvilli were sparse and almost all cells observed possessed a single cilium (Pl. 4, Fig. 15). TEM showed a high nucleus-cytoplasm ratio and there was a paucity of organelles except for dense structures with the morphological characteristics of lysosomes (Pl. 4, Fig. 16). Ciliated cells in the uterine epithelium

\section{PLATE 3}

Fig. 9. Day 18 of the oestrous cycle. Lipid is reduced to scattered droplets and there is evidence of degeneration. Note membranous fragments in lumen. Ly $=$ lysosome. $\times 2500$.

Fig. 10. Day 18 of the oestrous cycle. Secretory cells (S) have reverted to a flat-surfaced 5- or 6sided shape and ciliated cells $(\mathrm{C})$ have increased in numbers. $\times 1780$.

Fig. 11. Day 24 of the oestrous cycle, showing the considerable increase in ciliated cells which occurs at the end of the oestrus cycle in the possum. Debris has arisen mainly from glandular degeneration. $\times 385$.

Fig. 12. Day 24 of the oestrous cycle showing ciliogenesis (arrowed). $\times 5870$.

\section{PLATE 4}

Fig. 13. Uterus of anoestrous possum. Note continuing presence of ciliated cells (C). $\times 1910$.

Fig. 14. Possum after ovariectomy. The endometrial surface is corrugated and glandular openings (arrowed) are enlarged. $\times 290$.

Fig. 15. Possum after ovariectomy. Ciliated cells are extremely rare. Boundaries of secretory cells are marked by a peripheral ridge (arrowed). $s c=$ single cilium. $\times 4560$.

Fig. 16. Possum after ovariectomy. Note paucity of organelles. Ly $=$ lysosome $\times 3990$. 
were extremely rare 4 months after ovariectomy and those remaining did not have a full complement of cilia. Ciliated cells were never observed 14 months after ovariectomy.

\section{Morphometric analysis}

Cluster analysis was carried out on variables obtained from animals during the oestrous cycle (Table 1; Text-figs 1 \& 2). Large distance coefficients were recorded on Days 8 and 13 which supported morphological observations indicating that the greatest divergence from oestrous conditions occurred in mid-cycle (Text-fig. 1). Dendrograms derived from linkage tables obtained during the cluster analysis showed two groupings of data with those of mid-cycle linked separately to those at other stages (Text-fig. 2).

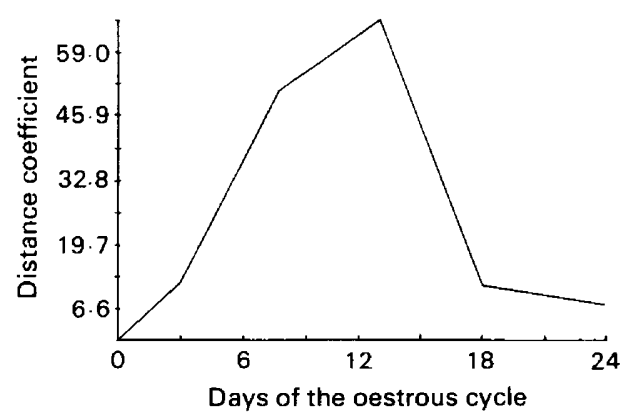

Text-fig. 1. Distance coefficients comparing values for each stage of the cycle with those at oestrus, i.e. this graph illustrates changes in the luminal epithelium during the oestrous cycle.

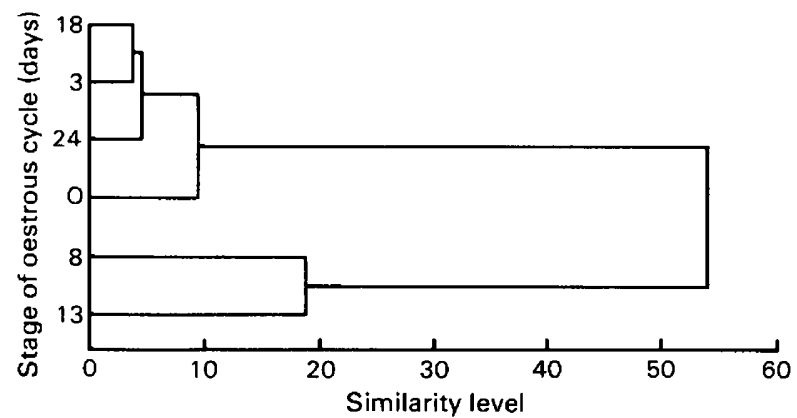

Text-fig. 2. Dendrograms derived from linkage tables obtained from the cluster analysis. These dendrograms link the most similar stages of the cycle first, followed by linkage of stages of greater difference. $\mathrm{O}=$ day of oestrus.

\section{Discussion}

Observations made in this study indicate that the uterine luminal epithelium of the oestrous possum is similar in appearance to that described for eutherians at oestrus (Brenner, 1970; Ludwig \& Metzger, 1976) with a large proportion of the epithelial surface occupied by ciliated cells. Secretory cells at this stage had a comparatively small apical surface area and appeared relatively inactive. 
The considerable amount of flocculent material which was present in the uterine lumen between oestrus and Day 3 (Pl. 1, Fig. 2) was almost certainly of glandular origin. It was frequently seen in the vicinity of the glandular openings and resembled morphologically the shell precursor, reported to be produced in large amounts in the superficial regions of the uterine glands at this stage (Hughes, 1974).

Between Days 4 and 13 of the oestrous cycle progesterone concentrations in the peripheral plasma progressively rise to a peak (Shorey \& Hughes, 1973) and this is associated with an accumulation of interstitial fluid in the uterine stroma and an increase in the thickness of the endometrium. The previously flat luminal surface became folded during mid cycle but did not reach the complexity reported in the uterus of some eutherians under conditions of high progesterone (Busch et al., 1981). A maximum distance coefficient was recorded on Day 13 reflecting maxima in both the values measured. The steady increase in secretory cell surface area may simply have been a device to accommodate the endometrial folding but may also have been related to the lipid which had accumulated in the apical cytoplasm. The membrane-bound vesicles present in the lumen of the uterus around Day 13 probably arose in the basal parts of the uterine glands because secretion from these was maximal around Day 13 (Shorey \& Hughes, 1973) and the granules in the lumen had a diameter consistent with those of the glands as well as resembling them morphologically. This does not preclude secretion of some of the lipid from the luminal epithelial cells, however, and a possible secretory function for these cells was supported by the presence of the small vesicles in the apical cytoplasm. Fusion of these vesicles with the apical plasma membrane may have given rise to the caveolae.

Ciliated cells, which occupied most of the endometrial surface area during the early stages of the cycle were reduced to about $6 \%$ of the total luminal surface area on Day 13 . The ciliated cells during mid-cycle might have remained unchanged whilst the secretory cells enlarged so that the altered ratio of the two cell types was merely the result of a 'dilution' of the ciliated cells, or deciliation of existing ciliated cells or division as well as enlargement of secretory cells might have taken place. Deciliation was not observed and even if the actual process occurred quite quickly it seems unlikely that the dense mass of filamentous material that was present in the apical cytoplasm of these cells (Shorey \& Hughes, 1973) would be readily dispersed, and non-ciliated cells containing this material were not observed. Mitotic figures were also rare at this stage, so the main reason for the altered secretory to ciliated cell ratio appeared to be the increase in size of the existing secretory cells.

Distance coefficients on Days 18 and 24 were small. The mean apical surface area of secretory cells on Day 18 had decreased to between one half and one third of the size measured on Day 13 and a further small decrease occurred between Days 18 and 24 of the oestrous cycle. At the same time plasma progesterone concentrations decreased to values similar to those measured at oestrus (Shorey \& Hughes, 1972). Shorey \& Hughes (1973) described sloughing of the glandular epithelium at the end of the oestrous cycle, followed by replacement from the accumulation of stromal cells around the glands. There has been speculation (Tyndale-Biscoe, 1955; Shorey \& Hughes, 1973) that a similar replacement process occurs in the luminal epithelium. However, observations made in this study indicate that the replacement occurs to only a limited extent. Single scattered cells were sloughed once involution had reached a certain point but shedding of sheets of epithelium as suggested by Tyndale-Biscoe (1955) was not observed. It is still not clear whether the lost cells are replaced from the stromal cells accumulated beneath the luminal epithelium or from mitotic activity. The discontinuous nature of the basement membrane at this stage may be an indication that infiltration of the epithelium by stromal cells was taking place as partial loss of the basement membrane is known to precede stromal cell replacement of the uterine glands (Shorey \& Hughes, 1973).

Ciliated cells predominated on Days 18 and 24 and whilst this may have been partly due to the decrease in the epithelial surface area occupied by secretory cells it was also related to the extensive ciliogenesis which took place at this stage. The relationship between ciliogenesis and plasma 
progesterone concentrations in the possum appeared to be similar to that observed for some eutherian species (Brenner, 1970; Ludwig \& Metzger, 1976; Verhage, Bariether, Jaffe \& Akbar, 1979) because cilia appeared in large numbers once progesterone values had decreased to approximately the levels found at oestrus. This may have been related to the oestrogen-blocking effect of progesterone described by Brenner (1970) because although plasma oestrogen levels on Day 18 in the possum have not been reported it was reasonable to assume that some oestrogen was produced by follicles developing before the next oestrus and large amounts of an oestradiol-like substance were reported on Day 24 of the cycle (Thorburn, Cox \& Shorey, 1971).

Morphometric analysis of the response of the uterine epithelial secretory cells has been carried out for the rabbit (Arnold \& Shorey, 1984), in which a similar pattern of mid-cycle increase in secretory cell size was recorded. However, comparison between the two species is difficult as at least part of the increase in secretory cell size in the rabbit was due to syncytial formation, an event which does not seem to occur in the possum.

The uterus of the possum appeared to undergo a greater degree of involution during anoestrus than was observed in the oviducts which were not greatly different in structure in anoestrous and cyclic animals (Arnold \& Shorey, 1985). The uterine epithelium might therefore be more sensitive to, or dependent upon, sufficient concentrations of oestrogen or progesterone or both to maintain secretory cell size and ciliated cell numbers than were the oviducts. Ovariectomy in the possum resulted in the mean apical surface area of secretory cells decreasing quite quickly to a value lower than any measured during the oestrous cycle or under anoestrous conditions. There was also almost complete deciliation of the epithelium. These changes took place during the first 4 months after ovariectomy, indicating that the effects of ovariectomy were manifested in the possum sooner than they were in eutherians such as the rabbit in which involution was incomplete 12 months after ovariectomy (R. Arnold, unpublished observations). A rapid response to ovariectomy has also been noted in the oviducts of the possum (Arnold \& Shorey, 1985), although the response of oviduct and uterine epithelia to circulating oestrogen and progesterone is quite different in intact animals.

We thank Dr S. Bradbury, Department of Human Anatomy, University of Oxford, for advice on the use of cluster analysis.

\section{References}

Anderson, T.L. (1982) Changes in the uterine luminal cell surface during early pseudopregnancy. Anat. Rec. 202, 7A, Abstr.

Arnold, R. \& Shorey, C.D. (1984) Structural and morphometric changes in the uterine epithelium of the rabbit during the latter stages of gonadotrophin induced pseudopregnancy. J. Anat. 139, 201.

Amold, R. \& Shorey, C.D. (1985) Structure of the oviducal epithelium of the brush-tailed possum (Trichosurus vulpecula). J. Reprod. Fert. 73, 9-19.

Busch, L.C., Kuhnel, W. \& Mootz, U. (1981) Scanning electron microscopical studies of the rabbit endometrium during estrus and preimplantation. In Three Dimensional Microanatomy of Cells and Tissue Surfaces, pp. 267-278. Eds L. J. A. diDio, P. M. Motta \& J. J. Allen. Elsevier/North Holland, Amsterdam.

Brenner, R.M. (1970) Hormonal control of cilia renewal in the primate oviduct: ultrastructural studies. In Progress in Gynecology, pp. 77-97. Eds S. Sturgis \& E. Taymore. Grune and Stratton, New York.

Davies, J. \& Hofiman, L.H. (1973) Studies on the progestational endometrium. I. Light microscopy, days $0-13$ of gonadotrophin induced pseudopregnancy. Am. J. Anat. 137, 423-426.
Davies, J. \& Hoffman, L.H. (1975) Studies on the progestational endometrium of the rabbit. II. Electron microscopy, day 0 to 13 of gonadotrophin induced pseudopregnancy. Am. J. Anat. 142, 335413.

Davis, J.C. (1973) Statistics and Data Analysis in Geology. John Wiley \& Sons, New York.

Eroschenko, V.P. (1982) Surface changes in oviduct, uterus and vaginal cells of neonatal mice after estradiol-17 $\beta$ and the insecticide clordecone ( $\mathrm{Ke}$ pone) treatment: a scanning electron microscope study. Biol. Reprod. 26, 707-720.

Finn, C.A. \& Porter, D.G. (1975) The Uterus. Elek Science, London.

Geissinger, H.D., Liptrop, R.M. \& Ackerly, C.A. (1979) Correlative uterine microscopy and hormone levels in cycling sows. In Scanning Electron Microscopy, 1979, Vol. III, pp. 177-184. Ed. O. Johari. SEM Inc., Chicago.

Hammer, R.E., Samarian, R. \& Mitchell, J.A. (1978) Alterations in SEM of the uterine epithelium of the rat, effects of ovarian steroid hormones. In Scanning Electron Microscopy, 1978, Vol. II, pp. 701-706. Ed. O. Johari. SEM Inc., Chicago. 
Hughes, R.L. (1974) The tertiary egg membranes of the marsupial Trichosurus vulpecula. Ph.D. Thesis, University of New South Wales.

Ludwig, H. \& Metzger, H. (1976) The Human Female Reproductive Tract. Springer-Verlag, Berlin.

Pilton, P.E. \& Sharman, G.B. (1962) Reproduction in the marsupial Trichosurus vulpecula. J. Endocr. 25, 119136.

Psychoyos, A. \& Madden, P. (1971) Scanning electron microscopy of the surface of the rat uterine epithelium during delayed implantation. J. Reprod. Fert. 26, $137-138$

Shorey, C.D. \& Hughes, R.L. (1972) Uterine glandular regeneration during the follicular phase in the marsupial Trichosurus vulpecula. Aust. J. Zool. 20, $235-247$.
Shorey, C.D. \& Hughes, R.L. (1973) Cyclic changes in the uterine endometrium and peripheral plasma concentrations of progesterone in the marsupial Trichosurus vulpecula. Aust. J. Zool. 21, 1-19.

Thorburn, G.D., Cox, R.I. \& Shorey, C.D. (1971) Ovarian steroid secretion rates in the marsupial Trichosurus vulpecula. J. Reprod. Fert. 24, 139, Abstr.

Tyndale-Biscoe, C.H. (1955) Observations on the reproduction and ecology of the brush-tailed possum Trichosurus vulpecula Kerr (Marsupialia) in New Zealand. Aust. J. Zool. 3, 162-184.

Verhage, H.G., Bariether, M.L., Jaffe, R.C. \& Akbar, M. (1979) Cyclic changes in ciliation, secretion and ciliated cell height of the oviductal epithelium in women. Am. J. Anat. 156, 505-522.

Received 5 October 1984 